\title{
Application of Strategic Environmental Assessment (SEA) to alleviate air pollution and the other impacts from power plant development
}

\author{
C. Poboon \\ School of Social and Environmental Development, \\ National Institute of Development Administration (NIDA), Thailand
}

\begin{abstract}
Development of power plants in Thailand has become very difficult for several years especially a coal-fired power plant as it draws a very strong resistance from local communities and NGOs. The most concern of these people is air pollution with perceived serious impact on the health of local people and the environment. On the other hand, demand for electricity in the country has been soaring in line with the economic development. Hence, this study attempted to find a new approach to respond to both people's concern and the demand of the country. Strategic Environmental Assessment (SEA) is a tool to assist decision-makers in considering benefits and impacts of proposed development policies, strategies or plans in a more comprehensive manner, in other words, to ensure the sustainable consequences of such development. A Regional Environmental Assessment (REA) which is a type of SEA focusing on analyzing the potential of a certain area against different kinds of development was selected for this study. The study started by interviewing relevant administrators and policy makers. In addition, public meetings with local people living around a power plant and also a proposed coal-fired power plant development site were organized. The 4-dimension REA then was developed in which initial indicators were proposed. This REA framework was presented for discussions in a stakeholder focus group meeting and in the second public meetings. Subsequently, a set of issues, indicators and criterion were established for analyzing the potential of any area against the development of power plant.
\end{abstract}

Keywords: air pollution, power plant development, Strategic Environmental Assessment. 


\section{Introduction}

Demand for electricity in Thailand has been substantially increasing during the past 3 decades due to rapid development of industry, expanding business activities and increasing electricity consumption in households. Unfortunately, development of power plant in Thailand has become very difficult especially coal-fired power plants as they drew very strong resistances from local communities and NGOs. The most concern of these people is air pollution with perceived serious impact on health of local people and the environment. In fact, their concerns are quite reasonable as they have been negatively impressed by the image of the old and biggest coal-fired power plant located in the North of Thailand. This power plant was very infamous on polluting the environment and posing serious impacts on health of the local people. This negative image of coal-fired is deeply perceived throughout the country so that when any coal-fired power plant project is proposed, a large group of local communities and NGOs will demonstrate their objections seriously. The objections are so serious that for the past 2 decades there is no new coal-fired power plant being built except one power plant in an industrial estate area in the Eastern Seaboard. As a result, Thailand now relies mostly on natural gas power plants which account about $70 \%$ of the total electricity demand of the country. This puts Thailand into a very unsecured situation since a large amount of natural gas supply are imported from neighboring countries. Hence, this study attempted to find a new approach to respond to both the people's concern and the demand of the country by proposing the Strategic Environmental Assessment (SEA) as a tool to help relevant government agencies, local people and NGOs in making decision towards the development of power plants.

\section{Methodology}

The study employed the qualitative research approach. Firstly, administrators and policy makers in the Ministry of Energy, Ministry of Resources and Environment, the Electric Generation Authority of Thailand and other relevant government officers were interviewed about the power plant development plan and policy, important impacts from the development and their suggestions for solving the problems. Secondly, public meetings with 2 communities living around a power plant site were organized to listen to their concerns about the impacts from the existing power plant and from the proposed coal-fired power plant construction. The 4-dimension REA was then developed comprising of environmental, economic, social and technological considerations in which initial indicators were proposed. This REA framework was presented for discussions in a stakeholder focus group meeting and later in the public meetings with the 2 communities in the proposed power plant construction area. Eventually, a set of adjusted issues and indicators were established for analyzing the potential of any area against different power plant development types. 


\section{Power plant development in Thailand and its problems}

Thailand's Power Development Plan 2012-2030 set up the target of power generation at the end of 2030 at 70,686 megawatt, of which 55,130 megawatt are from new power plants [1]. The added capacity can be classified as follows:
1. Renewable energy power plants
$14,580 \mathrm{MW}$
-purchase from domestic
9,481 MW
-purchase from neighboring countries
5,099 MW
2. Cogeneration
$6,476 \mathrm{MW}$
3. Combined cycle power plants
4. Thermal power plants
$25,451 \mathrm{MW}$
-coal-fired power plants
$8,623 \mathrm{MW}$
-nuclear power plants
4,400 MW
-gas turbine power plants
2,000 MW
$700 \mathrm{MW}$

It can be seen from the above figures that the next 20 years Thailand's power supply is still expected to rely mainly on natural gas. This is attributable to the experiences from the past that development of the other types of power plants are very difficult. The most famous case of conflict in power plant project construction is the Hin-krut and Bo-nok coal-fired power plant projects. These 2 projects were planned to build in Prachuab Keereekhun Province, upper Southern Thailand, in 1992. The local fisheries and communities were afraid of the impacts from air pollution, effluent and coal transportation so they exercised strong demonstrations and oppositions. Eventually, after several years of fighting, one of the opposition leaders was killed and the two projects were canceled [2]. Recently, there have been several coal-fired and biomass power plants being proposed in different regions but all of them have been seriously opposed by local people and NGOs. For example [3, 4]:

April 2011, 200 local people in Ubolratchathani Province, Northeastern Region, protested against a biomass power plant.

March 2012, 200 local people in Trang Province, Southern Region, demonstrated against a coal-fired power plant.

March 2012, 500 local people in Chacheongsao Province, Central Region, closed a road in objection of a natural gas power plant.

March 2012, 100 local people in Ubolratchathani Province, Northeastern Region, demonstrated against a nuclear power plant.

July 2012, local people living around an old power plant in Krabi Province, Southern Region, demonstrated against the construction of a coal-fired power plant within the existing power plant area.

September 2012, 600 local people in Songkhla Province, Southern Region, demonstrated against the extension of the existing natural gas power plant.

September 2012, 200 local people in Sra-kaew Province, Central Region, protested against a biomass power plant.

October 2012, 100 local people in Nakhonsritammaratch Province, Southern Region, submitted a letter opposing the construction of a coal-fired power plant to the chief of the district. 
This series of opposition incidents indicates clearly that the construction of power plants in Thailand is facing an intimidating obstacle. The target of added capacity set in the Power Development Plan 2012- 2030 is unlikely to be met if no effective approach is initiated and implemented.

\section{Application of the Strategic Environmental Assessment}

Strategic Environmental Assessment (SEA) is a tool to assist decision-makers in considering benefits and impacts of proposed development policies, strategies or plans in a more comprehensive manner, in other words, to ensure the sustainable consequences of such development. Fischer [5] described that

"SEA is a systematic decision support process, aiming to ensure that environmental and possibly other sustainability aspects are considered in PPP (policy, plan and program) making. In this context, SEA may support, first, public planning authorities and private bodies to conduct:

- structured, rigorous, participative, open and transparent EIA-based processes, particularly to plans and programs;

- participative, open and transparent, possibly non-EIA-based flexible processes to policies/visions and policy plans."

Based on its participative, transparent and flexible characteristics, SEA is therefore considered as a tool to help find a plausible solution to the near deadlock situation in development of power plants in Thailand.

Currently SEA can be classified in 3 types [6]:

1) Sectoral Based SEA - consider the implications of policy, plan or program of a particular sector;

2) Area Based SEA or Regional Environmental Assessment - consider the implications of policy, plan or program in a particular area or consider the potential of a particular are against different development alternatives;

3) Issued Based SEA - consider the implications of development by linking among sectoral, area, and issued based studies.

For this study, a Regional Environmental Assessment (REA) which is a type of SEA focusing on analyzing the potential of certain area against different kinds of development was selected as it can suggest the area that has potential in development of power plant at provincial, regional or national level. The potential covers of course the social aspect, particularly opinions of local communities.

The study started by interviewing administrators and policy makers in the Ministry of Energy, Ministry of Resources and Environment, the Electric Generation Authority of Thailand and other relevant government officers 
regarding the power plant development plan and policy, its concerned impacts and solutions. They mainly agreed with the Power Development Plan but they suggested that for the reason of energy security, the power generation should not rely too much on natural gas. Coal-fired and biomass power plants could be potential alternatives. However, there was a strong need to talk to local communities. In addition, all of them saw that the most important issue in development of the power plants is environmental impact, particularly air pollution and discharged wastewater.

After that, the study team conducted 2 public meetings in 2 communities located in Krabi Province, Southern Region. These 2 communities live around the old power plant which is also the target area of construction a new coal-fired power plant. A number of them opposed the construction as they were afraid of air pollution impact and impact from coal transportation, especially the local people from a village located down the wind. However, local people from another village saw that the new power plant could provide more benefits to the villagers.

Subsequently, the 4-dimension REA for analyzing the potential of particular area was developed in which initial indicators were proposed. The development was based on Thailand's framework on SEA study initiated by the Office of Natural Resources and Environmental Policy and Planning (ONEP). The issues and indicators for each dimension were employed from the opinions of the government officers, the local people and some previous studies. In fact, the 4dimension of REA comprising of environmental, economic, social and technological considerations is based on the Sustainable Development Criteria as shown in Figure 1.

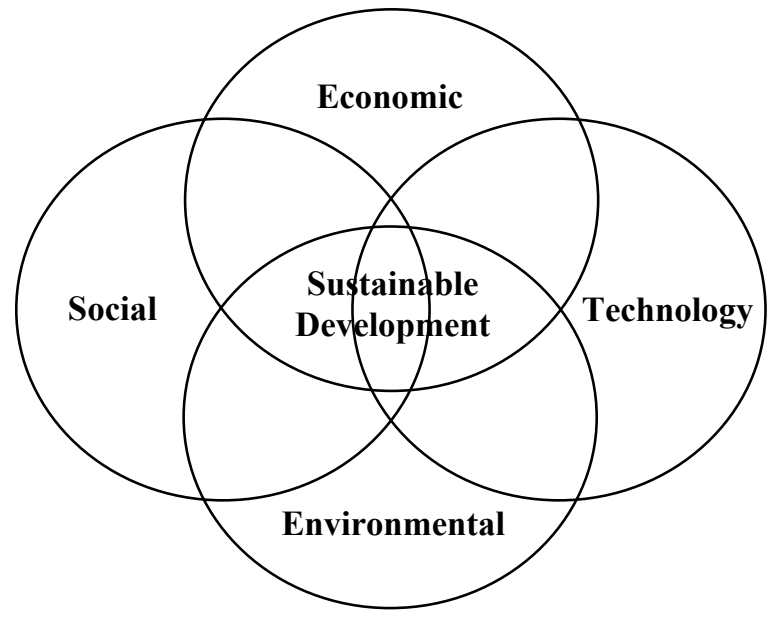

Figure 1: Framework of the REA considerations in this study. 
This REA framework was then presented for discussions in a stakeholder focus group meeting comprising of around 60 participants from a number of government agencies and state enterprises such as Ministry of Energy, Energy Policy and Planning Office, ONEP, Pollution Control Department, Environmental Quality control Department, Electricity Generation Authority of Thailand (EGAT), etc. as well as consultants, NGOs, mass media and academics. The meeting agreed that the application of SEA in decision making on power plant development was very necessary and beneficial to both the government and the local people. They also suggested some additional issues and indicators.

The adjusted REA was taken into the second public meetings in the 2 villages in Krabi Province. In the meeting in the first village, however, the local people did not pay much attention into details of the issues and indicators. They still focused mainly on their concerns about air pollution impact from the proposed power plant with the strong objection of the construction. Nevertheless, their opinions were somewhat useful so that the study team added more weight into the issues they were mostly concerned. The meeting in the second village also provided suggestions for adjusting the issues and indicators such as on their quality of life and safety, as well as the impacts on marine ecosystem.

The following Table 1 provides some examples of the final adjusted issues, indicators and weights of the REA which has been adopted by the Ministry of Energy and relevant agencies to use in development of power plant in Thailand.

From Table 1, each indicator has the criteria for the potential of the area against any proposed power plant development types. The potential could be classified as high, medium or low. The data will be gathered mainly from the secondary sources. The Geographical Information system (GIS) should be employed to analyze the data and to physically indicate the potential of the study area in a map form which is very helpful for decision makers and local people.

\section{Conclusions and discussions}

This study is one of the attempts to find solution for the almost deadlock in development of power plants in Thailand particularly coal-fired power plant which has bad reputation on its air pollution and other environmental impacts. The issues and indicators initiated by this study have derived from discussions with the relevant government administrators and officers, local people and other stakeholders which are likely to be well-developed and practical. However, they need to be proved by implementing with a real power plant development plan in any area. Furthermore, the approach used in conducting the public participation with the SEA process is very important. This study found that talking with local people on the power plant development issue was definitely sensitive as they did not trust the meeting organizer. This is the result of their negative experiences from several public hearings organized by the government agencies or consultants only in order to conform to the legislations but did not take the local people's opinions into consideration seriously [7]. 
Table 1: Issues, indicators and weights for the REA for power plant development in Thailand.

\begin{tabular}{|c|c|c|}
\hline Dimensions / Issues & Indicators & Weights \\
\hline \multicolumn{3}{|l|}{ Environmental (30) } \\
\hline \multirow[t]{9}{*}{ Natural Resources (5) } & Woodland & 0.5 \\
\hline & Wetland & 0.5 \\
\hline & Watershed & 0.5 \\
\hline & Mangrove Forest & 0.75 \\
\hline & Coral & 0.5 \\
\hline & Sea Grass & 0.5 \\
\hline & Biodiversity & 0.75 \\
\hline & Soil & 0.5 \\
\hline & Water / Underground Water & 0.5 \\
\hline \multirow[t]{10}{*}{ Environmental Quality (10) } & Air Quality & 1 \\
\hline & Noise & 1 \\
\hline & Surface Water Quality & 1 \\
\hline & Sea Water Quality & 1 \\
\hline & Landslide & 1 \\
\hline & Flood & 1 \\
\hline & Tsunami & 1 \\
\hline & Coastal Erosion & 1 \\
\hline & Land Use I & 1 \\
\hline & Land Use II & 1 \\
\hline \multirow{3}{*}{ Environmental Impacts (15) } & Air Pollution & 5 \\
\hline & Wastewater Management & 5 \\
\hline & Hazardous Waste Management & 5 \\
\hline \multicolumn{3}{|l|}{ Economic (20) } \\
\hline \multirow[t]{2}{*}{ Public Utility (5) } & Transportation & 2.5 \\
\hline & Demand for Electricity & 2.5 \\
\hline \multicolumn{3}{|l|}{ Social (30) } \\
\hline \multirow[t]{4}{*}{ Tourist Attraction (5) } & Ancient Remains & 1.25 \\
\hline & National Park & 1.25 \\
\hline & Sea / Beach & 1.25 \\
\hline & Number of Tourists & 1.25 \\
\hline Public Health (5) & Medical Personnel & 2.5 \\
\hline \multirow[t]{2}{*}{ Population (5) } & Population Density & 1.5 \\
\hline & Migration & 1 \\
\hline \multirow{2}{*}{$\begin{array}{l}\text { Acceptance and Participation of Local } \\
\text { People (15) }\end{array}$} & Public Participation & 5 \\
\hline & Conflict from Development Project & 5 \\
\hline \multicolumn{3}{|l|}{ Technology (20) } \\
\hline Efficiency (5) & Efficiency of Technology & 5 \\
\hline \multirow[t]{2}{*}{ Green Technology (5) } & Use of Clean Technology & 2.5 \\
\hline & Environmental/Safety Standards & 2.5 \\
\hline Regulations (5) & Enforcement of Laws / Regulations & 5 \\
\hline
\end{tabular}

\section{Recommendations}

1) The established set of issues, indicators and criterion from this study has to be implemented to see their accuracy and efficiency in analyzing the potential of any interested area. The adjustment of this REA is welcome to make it practical in Thailand's context. 
2) The most important step in application of the SEA is public participation. Hence, there is a strong need to employ effective and appropriate public participation approaches. The implementation of this REA also needs experienced specialists who can select and conduct meaningful public participations which are appropriate for particular group of local people.

\section{References}

[1] Energy policy and planning office, Ministry of Energy, Summary of Thailand Power Development Plan 2012-2030 (PDP2010: Revision 3), pp. 8-10, 2012.

[2] Manager Online, Against Power Plant in Trang, http://www.manager.co.th/South/ViewNews.aspx?NewsID=9550000077118

[3] Plerngmorakot, Thairath Online, Against Power Plant, http://www.thairath.co.th/column/region/no1vipha/258441

[4] Manager Online, When the Community Fights, http://www.manager.co.th /Daily/ViewNews.aspx?NewsID=9540000026126

[5] Fischer, T., Theory \& Practice of Strategic Environmental Assessment, Earthscan: London, pp. 2, 2007.

[6] Office of Natural Resources and Environmental Policy and Planning, Strategic Environmental Assessment: SEA, B.V. Offset: Bangkok, pp. 4, 2011.

[7] Wirutskulshai, U., Sajor, E., and Coowanitwong, N., Importance of context in adoption progress in application of strategic environmental assessment: Experience of Thailand, Environmental Impact Assessment Review, Vol. 31, pp. 352-359, 2011. 